\title{
MBBR+two-stage $A O$ in upgrading and rebuilding project $O$ a sewage treatment plant in north China
}

\author{
Shen Dongmei ${ }^{1}$, Yu Cairui ${ }^{1,}{ }^{*}$, Gao Yulan ${ }^{1}$, Song Xinwei ${ }^{1}$ and Chu Jingsong ${ }^{2}$ \\ ${ }^{1}$ West Anhui University, Architecture and Civil Engineering Department, 237012 Lu'an, China \\ ${ }^{2}$ Planning and Architectural Design Research Institute of Hunan City University, Beijing Haidian Branch, 100089, Beijing, China
}

\begin{abstract}
A sewage treatment plant is located in the middle of Inner Mongolia. There is a large amount of slaughtering wastewater in the influent with high COD, SS, low annual temperature, poor nitrogen removal effect, and the effluent quality is only grade B. In order to solve the above problems, A\A\O-MBBR + high efficiency sedimentation tank continuous sand filter process was adopted to establish a new anaerobic tank and a first stage AO-MBBR bioreactor. The selection tank and partial oxidation ditch were transformed into the second stage A pool (anoxic pool), and the remaining part of the existing oxidation ditch was transformed into the second stage $\mathrm{O}$ pond (aerobic pool), which further removed phosphorus and reduced the SS in the sewage, and solved the problem of low temperature biological treatment in winter in the north of China. The quality of the effluent reached level A after the upgrading.
\end{abstract}

\section{Introduction}

Biological nitrogen removal is the most common treatment method. Environment temperature not only affects the growth of nitrifying bacteria, but also affects the activity of nitrifying bacteria. Previous studies have shown that the optimal growth temperature of nitrifying bacteria was $25-30{ }^{\circ} \mathrm{C}$ [1], i.e., the nitrifying rate decreases significantly when the growth temperature was less than $15^{\circ} \mathrm{C}$, and the activity of nitrifying bacteria also decreases significantly; while its temperature is less than $5{ }^{\circ} \mathrm{C}$, the life activity of nitrifying bacteria had almost ceased. U. Sudarno et al. [2] investigated the effect of temperature variation with nitrification, and the results showed that when the temperature increased from $12.5{ }^{\circ} \mathrm{C}$ to $40{ }^{\circ} \mathrm{C}$, the ammonia oxidation rate increased; while the temperature decreased to $6^{\circ} \mathrm{C}$, the activity of nitrifying bacteria was very low.

Low temperature has a significant inhibition effect on denitrification. Zhong et al. [3] investigated the denitrification in Taihu Lake sediment. It was found that denitrification rate showed seasonal change after several months of experimental analysis. U. Welander et al. [4] conducted the operation performance of denitrification process at low temperature $\left(3-20^{\circ} \mathrm{C}\right)$, which showed that the denitrification rate of the reactor at $3{ }^{\circ} \mathrm{C}$ was only $55 \%$ of that at $15{ }^{\circ} \mathrm{C}$. The winter water temperature in the north of China was about $10^{\circ} \mathrm{C}$, which was quite different from the suitable growth temperature of nitrification and denitrification functional bacteria, resulting in the decline of biological denitrification treatment effect in winter and even unable to reach the standard [5].
According to national energy conservation and emission reduction, more and more urban sewage treatment plants have raised their emission standards from the original level B in GB18918-2002 to the level A or higher standard. That is to say, the quasi emission limits of NH4+-N and TN are $8 \mathrm{mg} / \mathrm{L}$ and $20 \mathrm{mg} / \mathrm{L}$, respectively, to $5 \mathrm{mg} / \mathrm{L}$ and $15 \mathrm{mg} / \mathrm{L}$. Therefore, many sewage plants have been transformed. In this paper, we take a sewage plant in north China into consideration and achieve the national standard level A by the renovation [6-8].

\section{Project introduction}

A sewage plant is located in the central part of Inner Mongolia, which is characterized by the semi-arid continental climate in the middle temperate zone, with $1.7{ }^{\circ} \mathrm{C}$ average annual temperature and $287.2 \mathrm{~mm}$ average annual precipitation. The surface water system is underdeveloped and water-deficient zone, where the main water supply aquifer is made of the quaternary upper pleistocene series sand, gravel, sand and gravel layer, as shown in Fig. 1.

\footnotetext{
* Corresponding author: yucr_2000@163.com
} 


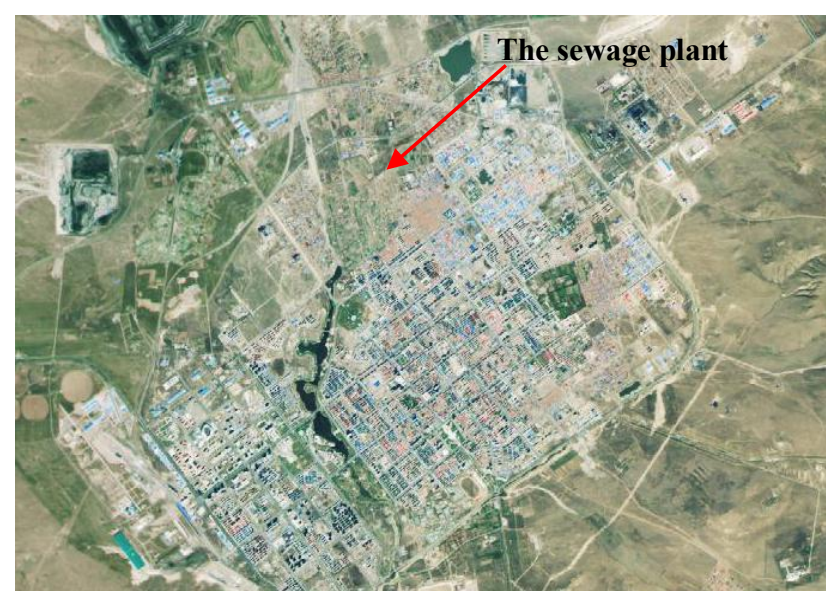

Fig. 1. The sewage plant location layout

The inflow scale of sewage has not reached the expected $40000 \mathrm{~m}^{3} / \mathrm{D}$ design scale after the operation. In fact, there were a lot of slaughtering wastewater in the influent, which had high SS value and complex pollutant types. And the main pollutant indexes were much higher than the original design values. In this zero, the ambient temperature is low all the year round, which resulted in the poor denitrification effect, and the effluent quality only met the first level B of GB18918-2002. In order to realize the sustainable development of water resources, as well as the low temperature, little rain all year round and the shortage of water resources, the effluent of the sewage plant would be used as the water source of the regeneration water purification plant, which was to provide industrial water for the power plants and openpit coal mines in the city. Therefore, the sewage plant is in urgent need of upgrading, and raising the effluent standard to level A.

\section{The original process and the existing problems}

The DE oxidation ditch process was adopted in the first stage of the sewage plant, and the excess sludge is mechanically dewatered after being concentrated. The specific process flow is shown in Fig. 2.

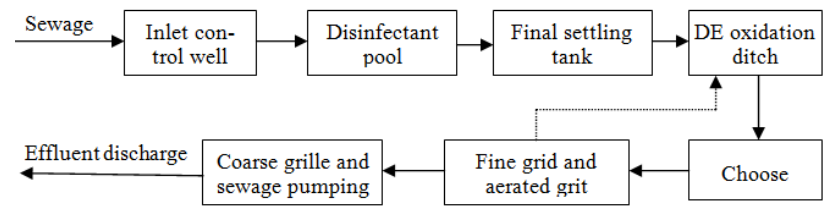

Fig. 2. Original process flow chart of sewage plant.

The sewage inflow was only about $28,000 \mathrm{~m}^{3} / \mathrm{d}$, which was far lower than the expected design scale of $40,000 \mathrm{~m}^{3} / \mathrm{d}$ after the operation of the sewage plant. The pollutant index was much higher than the designed index due to the fact that the actual inlet water of this sewage plant contained a large amount of slaughterhouse waste water. According to the measurement, the maximum inlet water $\mathrm{COD}_{\mathrm{cr}}$ and ammonia nitrogen reached 2000 $\mathrm{mg} / \mathrm{L}$ and $120 \mathrm{mg} / \mathrm{L}$, respectively. The high inlet water load and the $1.7{ }^{\circ} \mathrm{C}$ average annual temperature in this zero were not conducive to biochemical treatment, which resulted in the failure to reach the effluent level A. Meanwhile, the following problems often occurred in operation: (1) the high COD concentration of inlet water, the high ammonia nitrogen, and the low annual average temperature affected the removal of ammonia nitrogen. (2) the composition of slaughterhouse wastewater is complex, i.e., the high content of organic pollutants, and high SS value. Hence, the existing biochemical treatment system was difficult to effectively remove to a low level. (3) the alternating operation mode of DE oxidation ditch was not conducive to sewage treatment at low temperature.

\section{The upgrading and reconstruction selection}

\subsection{The original inlet water quality}

It has an important influence on the process selection of sewage plant, which included the influent water quality, effluent water quality as well as sewage treatment degree of urban sewage plant. In recent years, the monitoring index of sewage plant were shown in Fig.3. Combined with the historical manual monitoring and water quality test data in July 2015, the inlet water quality was designed by the sewage treatment plant of this project, and the results were shown in Table 1.
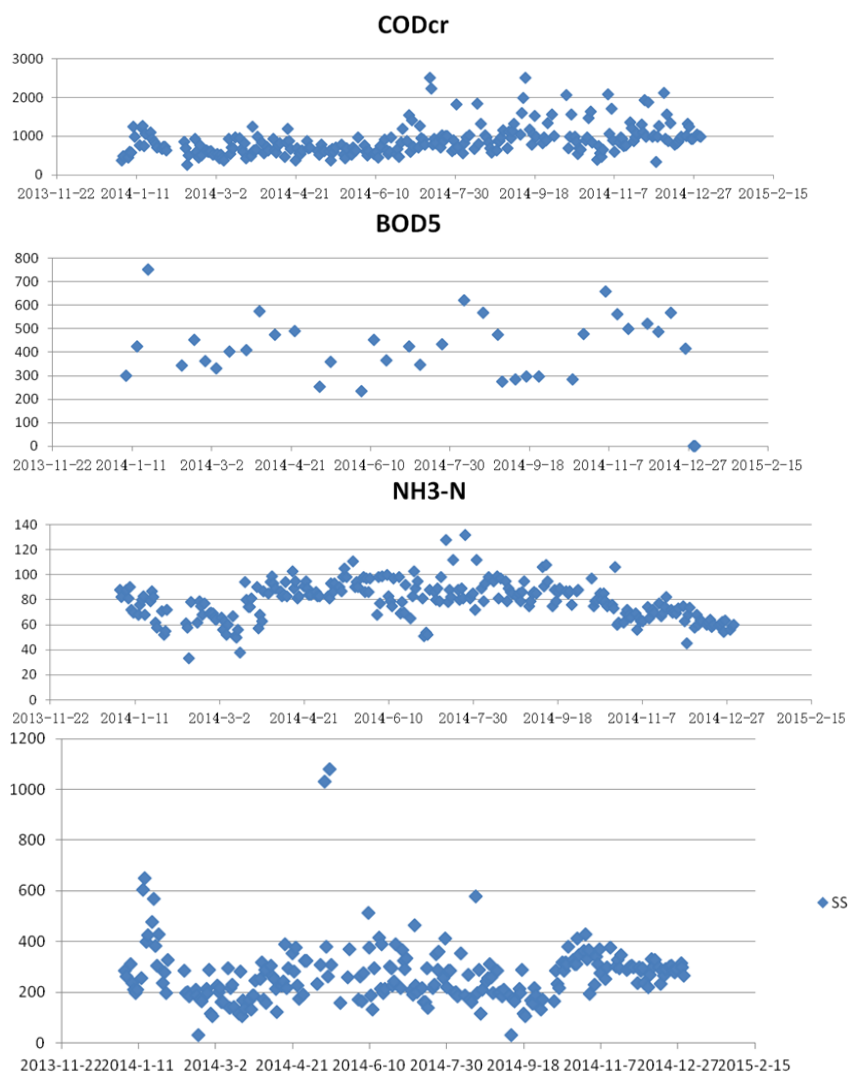

Fig. 3. Water quality monitoring index of sewage plant. 
Table 1. The designed inlet water quality of the sewage plant.

\begin{tabular}{|c|c|c|}
\hline S.N. & Items & $\begin{array}{c}\text { Designed inlet } \\
\text { water quality }\end{array}$ \\
\hline 1 & $\begin{array}{c}\text { Chemical oxygen } \\
\text { demand(CODcr) }\end{array}$ & $\leq 2000$ \\
\hline 2 & $\begin{array}{c}\text { Biochemical oxygen } \\
\text { demand(BOD5) }\end{array}$ & $\leq 800$ \\
\hline 3 & Total nitrogen(TN) & $\leq 130$ \\
\hline 4 & $\begin{array}{c}\text { Ammonia nitrogen(NH3- } \\
\text { H) }\end{array}$ & $\leq 110$ \\
\hline 5 & Total phosphorus(TP) & $\leq 14.0$ \\
\hline 6 & Suspended solids(SS) & $\leq 380$ \\
\hline 7 & Animal and vegetable oil & $\leq 190$ \\
\hline
\end{tabular}

According to the analysis of Fig. 3 and Table 1, the annual COD was maintained between 500-1000, which was easy to cause investment waste if designed in term of high load. Influenced by slaughterhouse wastewater, the COD of the second half year (slaughterhouse was busy in mass production) was higher than that of the first half year; and most of $\mathrm{BOD}_{5}$ was in the range of 300-600 $\mathrm{mg} / \mathrm{L}$; as well as the annual influent $\mathrm{NH}_{3}-\mathrm{N}$ was mostly in the range of $80-100 \mathrm{mg} / \mathrm{L}$, in which the total days of exceeding $100 \mathrm{mg} / \mathrm{L}, 120 \mathrm{mg} / \mathrm{L}$ were 9 days and 2 days, respectively; and most of the influent $\mathrm{SS}$ were in the range of 200-400 mg/L and more than $380 \mathrm{mg} / \mathrm{L}$ was 16 days.

\subsection{Selection of process route}

According to the characteristics of the influent water quality and the local characteristics of the sewage plant, and the above sewage plant has the following characteristics:(1) it was the key and difficulty of high ammonia nitrogen removal and sludge concentration increase at low temperature,(2) insufficient phosphorus content in raw water,(3) the influence of hair and grease in slaughterhouse wastewater on the treatment process should be fully considered,(4) the value of $\mathrm{B} / \mathrm{C}$ was mostly between 0.4 and 0.6 , and the biological denitrification could be realized when BOD5/TN was more than 3 . Thus, the key point was to increase the biomass under low temperature. In this paper, two schemes will be used for comparison. And compare the two schemes, as shown in Table 2.

Scheme 1: $\mathrm{A} \backslash \mathrm{A} \backslash \mathrm{O}-\mathrm{MBBR}+$ High efficiency sedimentation tank + Continuous sand filter process. New oil separation sedimentation tank and air flotation tank pretreatment process, new anaerobic tank and primary AO-MBBR biological tank; transformation of existing selection tank and partial oxidation ditch into secondary a tank (anoxic tank); transformation of the remaining part of the existing oxidation ditch into secondary $\mathrm{O}$ tank (aerobic tank). In order to further remove phosphorus and reduce SS in sewage, a high efficiency sedimentation tank and a continuous sand filter were added for further treatment [9-11].
Scheme 2: A $\backslash A \backslash O-M B R+$ Chemical phosphorus removal process. New oil separation sedimentation tank, membrane grid and air flotation tank pretreatment process; transformation of the original selection tank and oxidation ditch into $20000 \mathrm{~m} 3 / \mathrm{D}$ biochemical tank I $(\mathrm{A} / \mathrm{A} / \mathrm{O}+\mathrm{A} / \mathrm{O})$; new $20000 \mathrm{~m} 3 / \mathrm{D}$ biochemical tank II $(\mathrm{A} / \mathrm{A} / \mathrm{O}+\mathrm{A} / \mathrm{O})$. Membrane bioreactor (MBR) process was used to replace the original final sedimentation tank for sludge water separation. In order to ensure the phosphorus removal effect, chemicals were added to the effluent of $\mathrm{O}$ tank for chemical phosphorus removal [6, $12]$.

Table 2. Comparison of process schemes

\begin{tabular}{|c|c|c|c|}
\hline \multirow{2}{*}{ S.N. } & \multirow{2}{*}{ Comparative items } & \multicolumn{2}{|c|}{ Sewage treatment schemes } \\
\hline & & Scheme 1 & Scheme 2 \\
\hline 1 & Effluent quality & $\begin{array}{l}\text { Conducive to the } \\
\text { growth of nitrifying } \\
\text { bacteria, low tempera- } \\
\text { ture resistance, good } \\
\text { nitrogen removal effect, } \\
\text { Chemical phosphorus } \\
\text { removal alone, appro- } \\
\text { priate control, good } \\
\text { effect, water stable } \\
\text { standard. }\end{array}$ & $\begin{array}{l}\text { The denitrification } \\
\text { effect is greatly af- } \\
\text { fected by activated } \\
\text { sludge process in } \\
\text { winter; } \\
\text { Chemical phosphorus } \\
\text { removal needs to be } \\
\text { done in the biological } \\
\text { section; } \\
\text { Good SS and COD of } \\
\text { effluent. }\end{array}$ \\
\hline 2 & $\begin{array}{l}\text { Environmental } \\
\text { adaptability }\end{array}$ & $\begin{array}{l}\text { Good low temperature } \\
\text { adaptability }\end{array}$ & $\begin{array}{l}\text { Common low tem- } \\
\text { perature adaptability }\end{array}$ \\
\hline 3 & Floor area & Large & Small \\
\hline 4 & $\begin{array}{l}\text { Utilization of ex- } \\
\text { isting facilities }\end{array}$ & $\begin{array}{l}\text { Make almost full use of } \\
\text { exiting facilities }\end{array}$ & $\begin{array}{l}\text { Remove secondary } \\
\text { tanks }\end{array}$ \\
\hline 5 & Engineering cost & Common & High \\
\hline 6 & Operation cost & $\begin{array}{l}\text { Increase } 0.22 \text { yuan/ton } \\
\text { sewage }\end{array}$ & $\begin{array}{l}\text { Increase } 0.5 \text { yuan/ton } \\
\text { sewage }\end{array}$ \\
\hline 7 & $\begin{array}{l}\text { Construction diffi- } \\
\text { culty }\end{array}$ & $\begin{array}{l}\text { Almost no impact on } \\
\text { production, small diffi- } \\
\text { culty, short time }\end{array}$ & $\begin{array}{l}\text { Impact on production, } \\
\text { lager difficulty }\end{array}$ \\
\hline 8 & $\begin{array}{l}\text { operational circum- } \\
\text { stances }\end{array}$ & $\begin{array}{l}\text { Simple management, } \\
\text { small difficulty }\end{array}$ & $\begin{array}{l}\text { easy to block the } \\
\text { membrane module, } \\
\text { needs frequent flush- } \\
\text { ing and complicated } \\
\text { operation manage- } \\
\text { ment. }\end{array}$ \\
\hline 9 & $\begin{array}{l}\text { Maintenance Man- } \\
\text { agement }\end{array}$ & $\begin{array}{l}\text { Low maintenance re- } \\
\text { quirements and small } \\
\text { workload }\end{array}$ & $\begin{array}{l}\text { High maintenance } \\
\text { requirements, high } \\
\text { workload }\end{array}$ \\
\hline
\end{tabular}

It can be seen that there are many technical adaptability applications of the two schemes through the comparison of the above Table. 2. However, MBBR scheme had strong adaptability to low temperature because of good effluent quality, low cost, small construction, small difficulty in construction, operation and maintenance. Although it covered a large area, the water plant had enough site to meet the MBBR Process. Many successful cases were employed at home and abroad due to mature design method. Therefore, the MBBR scheme was finally selected, and the flow chart of upgrading scheme is shown in Fig. 4.

\section{Design of main parameters}

According to the description in Section 2, MBBR Process was selected for the project to build or reconstruct the existing structures. And the project would build 6 new buildings and 3 new ones, and the specific structures were shown in Table. 3 . 


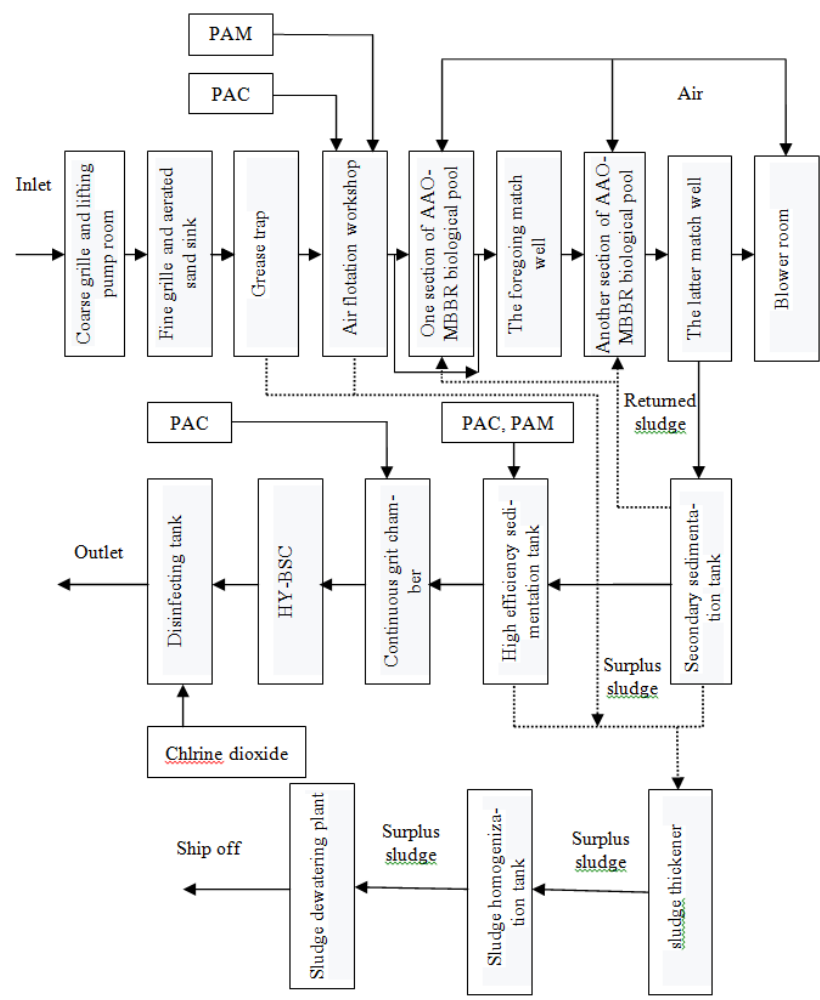

Fig. 4 The flow chart of upgrading MBBR scheme

Table 3. Newly-built and renovated structures

\begin{tabular}{|l|l|l|l|}
\hline Items & Construction & Technical parameters(length $\times$ width) & $\begin{array}{l}\text { Num- } \\
\text { ber }\end{array}$ \\
\hline $\begin{array}{l}\text { New- } \\
\text { ly-built }\end{array}$ & Grease trap & $25.4 \mathrm{~m} \times 42.05 \mathrm{~m}+10.2 \mathrm{~m} \times 16.1 \mathrm{~m}$ & 2 \\
\cline { 2 - 4 } & Air flotation workshop & $42.8 \mathrm{~m} \times 26.7 \mathrm{~m}+13.2 \mathrm{~m} \times 3.0 \mathrm{~m}$ & 1 \\
\cline { 2 - 4 } & Biological pool & $62.9 \mathrm{~m} \times 97.3 \mathrm{~m}$ & 1 \\
\cline { 2 - 4 } & $\begin{array}{l}\text { High efficiency sedimen- } \\
\text { tation tank }\end{array}$ & $15.7 \mathrm{~m} \times 6.3 \mathrm{~m}+27.8 \times 21.5 \mathrm{~m}$ & 1 \\
\cline { 2 - 4 } & Continuous sand filter & $17.7 \mathrm{~m} \times 21.6 \mathrm{~m}+3.0 \times 3.95 \mathrm{~m}$ & 1 \\
\hline \multirow{2}{*}{$\begin{array}{l}\text { Reno- } \\
\text { vated }\end{array}$} & Blower room & $36 \mathrm{~m} \times 9 \mathrm{~m}$ & 1 \\
\cline { 2 - 5 } & Select pool & $\begin{array}{l}22.35 \mathrm{~m} \times 10.9 \mathrm{~m}(\text { Replaced with a } \\
\text { pre-dispensing well) }\end{array}$ & 1 \\
\cline { 2 - 5 } & DE oxidation ditch & $\begin{array}{l}\text { Transformed into a second stage hypox- } \\
\text { ia/second stage aerobic pool }\end{array}$ & 1 \\
\cline { 2 - 4 } & Sludge dewatering room & $37.2 \mathrm{~m} \times 9 \mathrm{~m}$ & 1 \\
\hline
\end{tabular}

It should be noted that a newly built oil separation sedimentation tank was divided into two grids, in which the average water surface load and hydraulic retention was $2.56 \mathrm{~m}^{3} /\left(\mathrm{m}^{2} . \mathrm{h}\right), 1.1 \mathrm{~h}$, respectively. In view of the high content of total nitrogen in inlet water, two-stage $\mathrm{AO}$ process is adopted for sewage biological treatment in this project. The effluent from partial air flotation treatment exceeds the first stage AAO-MBBR biological tank and directly enters the second stage AO biological tank. Sludge concentration: $4000 \mathrm{mg} / \mathrm{L}$, anaerobic residence time: $2.0 \mathrm{~h}$, facultative residence time: $6.2 \mathrm{~h}$.

\section{Results analysis}

\subsection{Analysis of operation effect}

The project has been completed and put into operation in the second half of 2015. So far, the sewage plant has been good result in operation. In this section, we will compare and analyze the effect before and after the sewage plant transformation. The operation of the transformed sewage plant on May 30, 2018 was shown in Table 4. It can be seen that the COD and $\mathrm{BOD}_{5}$ met the level A of discharge standard for GB18918-2002, the ammonia nitrogen and SS effluent met the national standard, the total phosphorus content of effluent is high, and chemical agent can be added to assist phosphorus removal..

Table 4. Monitoring parameters of the sewage plant.

\begin{tabular}{|c|c|c|c|c|}
\hline Items & $\begin{array}{c}\text { Total } \\
\text { influent }\end{array}$ & $\begin{array}{c}\text { Total } \\
\text { effluent }\end{array}$ & $\begin{array}{c}\text { Effluent } \\
\text { standard }\end{array}$ & $\begin{array}{c}\text { Removal } \\
\text { rate (\%) }\end{array}$ \\
\hline COD & 836 & 42 & 50 & 94 \\
\hline BOD 5 & 278 & 10 & 10 & 96 \\
\hline $\mathrm{TN}$ & 124 & 40 & 15 & 67 \\
\hline $\mathrm{TP}$ & 7.49 & 0.73 & 0.5 & 90 \\
\hline $\mathrm{NH}_{3}-\mathrm{N}$ & 87.7 & 0.16 & 5 & 99.8 \\
\hline $\mathrm{SS}$ & 13 & 4 & 10 & 69 \\
\hline
\end{tabular}

\subsection{Pollutant reduction}

The construction of upgrading project can further remove pollutants in water, such as SS, phosphate and other nutrients. It not only protects the ecological environment, but also beautifies the urban environment through the implementation of transformation. After the completion of the project, the amount of pollutants will be reduced every day, which was discharged into the surrounding waters, as shown in Table. 5 (with a scale of $40,000 \mathrm{~m}^{3} / \mathrm{d}$ ). It can be seen that the completion of the project significantly improved and protected the water environment of the surrounding River Basin, reduced the pollution of urban sewage to the water environment, and more conducived to the realization of the water environment goal of the river basin.

Table 5. List of pollutant removal amount.

\begin{tabular}{|c|c|c|c|c|c|c|}
\hline Items & $\begin{array}{c}\text { BOD } \\
5\end{array}$ & $\begin{array}{c}\mathrm{COD} \\
\mathrm{Cr}\end{array}$ & $\mathrm{SS}$ & $\begin{array}{c}\mathrm{NH}_{3-} \\
\mathrm{N}\end{array}$ & $\mathrm{TN}$ & $\mathrm{TP}$ \\
\hline $\begin{array}{c}\text { Designed water } \\
\text { inflow(mg/L) }\end{array}$ & 2000 & 800 & 380 & 130 & 120 & 14 \\
\hline $\begin{array}{c}\text { Designed water } \\
\text { outflow(mg/L) }\end{array}$ & 50 & 10 & 10 & 15 & 8 & 0.5 \\
\hline $\begin{array}{c}\text { Total } \\
\text { removal(t/d) }\end{array}$ & 78 & 31.6 & 14.8 & 4.6 & 4.48 & 0.54 \\
\hline
\end{tabular}

\section{Conclusion}

After a period of operation, the operation result is good and the expected goal is achieved. The several conclusions are drawn as follows:

(1) MBBR+two-stage AO process can effectively resist low temperature, improve sludge concentration, and strengthen denitrification effect. The effluent meets the level A standard of GB18918-2002, which provide water source for regeneration water purification plant, and realizing high efficiency and sustainable utilization of water. 
(2) The original structure was made full use of the treatment process, therefore, the transformation cost was moderate, and the operation cost is low. It is suitable for the project of low temperature water shortage and reuse of water in North China.

(3) Considering the large proportion of industrial sewage in the sewage planning within the service scope of the project, the sewage discharge index of each enterprise in the area shall be strictly controlled, and the sewage can be discharged into the drainage pipeline only after reaching the index required by the state.

(4) The content of phosphorus in the effluent was too high. It was necessary to improve the process, assist chemical phosphorus removal and reduce the content of phosphorus.

\section{Acknowledgments}

This research was supported by the grants from Natural science research project of West Anhui University (WXZR201628)

\section{References}

1. Mauret, M., et al., Application of experimental research methodology to the study of nitrification in mixed culture. Water Science and Technology, 1996. 34(1): p. 245-252.

2. Sudarno, U., J. Winter, and C. Gallert, Effect of varying salinity, temperature, ammonia and nitrous acid concentrations on nitrification of saline wastewater in fixed-bed reactors. Bioresour Technol, 2011. 102(10): p. 5665-73.

3. Zhong, J., et al., Seasonal variation of potential denitrification rates of surface sediment from Meiliang Bay, Taihu Lake, China. Journal of Environmental Sciences, 2010. 22(7): p. 961-967.

4. 4. Welander, U. and B. Mattiasson, Denitrification at low temperatures using a suspended carrier biofilm process. Water Research, 2003. 37(10): p. 2394-2398.

5. Lundgaard, A.S.B., et al., Nitrogen cycling and bacterial community structure of sinking and aging diatom aggregates. Aquatic Microbial Ecology, 2017. 79(2): p. 85-99.

6. Sun Ying, L.J., Design of Upgrading Reconstruction Project of Municipal Waste water Treatment Plant. China watwe \& waste water, 2010. 26(10): p. 104106.

7. Duan Cunli, G.R., Cheng Juntao,Bi Xuejun, Song Meiqin, Design and Operation of Upgrading and Retrofitting Project of Qingdao Licunhe WWTP. China watwe \& waste water, 2011. 27(12): p. 66-70.

8. Sun Xianpeng, B.S., Selection of process and effects analysis of the upgrading and reconstruction for biochemical reaction of tuan dao waste treatment plan. journal of Qing Dao Technological University 2013. 34(01): p. 74-79.
9. Yang Fan, Z.L., Wang Xue, Application of Stereosopic Ecological Biofilm Reactor in Wastewater Treatment Process with High Emission Standard. China watwe \& waste water, 2018. 34(06): p. 60-64.

10. Liu Jianguang, H.C., Xie Yongjun, Wwang Dan, Study onTwo-stage MBBR for Advanced Treatment of Domestic Sewage with High Ammonia Nitrogen. China water \& Waste water, 2011. 27(03): p. 90-93.

11. Sun Xiaojie, W.J., Zhao Xiaoqin, Wang Dunqiu, Zhu Yinian, Discussion on upgrading and reconstruction of urban wastewater treatment plants in China. Environmental Engineering, 2013. 31(06): p. 12-15.

12. FU Chun-ping, Z.C.-h., Deng Chun-guang, Relationship Between $\mathrm{pH}$ Value of the Water and Release Silt Bottom of Nitrogen \&Phosphate in the Three Gorges. Journal of Chongqing University, 2004. 27(10): p. 125-127. 